\title{
Passion fruit by-product as a substitute for Tifton 85 hay in diets for dairy heifers
}

\section{Coproduto do maracujá em substituição ao feno de capim Tifton 85 em dietas para novilhas leiteiras}

\author{
Mércia Regina Pereira de Figueiredo ${ }^{1 *}$; Eloisa de Oliveira Simões Saliba ${ }^{2}$; \\ Geraldo Sérgio Senra Carneiro Barbosa ${ }^{3}$; Filipe Aguiar e Silva ${ }^{4}$; \\ Cecília Ribeiro da Mota e Silva ${ }^{4}$; Andressa Nathalie Nunes; \\ Guilherme Rocha Moreira ${ }^{5}$; Tássia Ludmila Teles Martins ${ }^{4}$
}

\begin{abstract}
This study was undertaken to examine the intake, nutrient digestibility, protein and energy balance and feeding behavior of dairy heifers fed diets in which Tifton 85 bermuda grass (Cynodon $s p$ ) hay was substituted by a passion fruit (Passiflora edulis) by-product. Sixteen Holstein $\times$ Zebu crossbred heifers with an average weight of $363.00 \pm 27.7 \mathrm{~kg}$ were assigned to four treatments represented by diets in which levels of a passion fruit by-product $(0,12,24$ and $36 \%$; dry matter basis) were added as a substitute for Tifton 85 bermuda grass. The intakes of crude protein and ether extract $(\mathrm{P}>0.05)$ rose as the by-product was added to the diets. Nitrogen intake, absorbed nitrogen and urinary nitrogen also increased with the inclusion of the by-product. Passion fruit by-product can be included in diets for dairy heifers up to the level of $36 \%$.
\end{abstract}

Key words: Feeding behavior. Intake. Digestibility. Passion fruit.

\section{Resumo}

Objetivou-se avaliar a inclusão do coproduto do maracujá (Passiflora edulis), em substituição ao feno de capim tifton 85, sobre o consumo, a digestibilidade dos nutrientes, o balanço proteico e energético e o comportamento ingestivo animal. Dezesseis novilhas mestiças Holandês x Zebu, com peso médio de $(363,00 \pm 27,7 \mathrm{Kg})$ foram distribuídas em quatro tratamentos e receberam dietas com substituição do feno de capim Tifton 85 (Cynodon $s p$ ) pelo coproduto do maracujá em $(0,12,24,36 \%$ da MS). Os consumos de proteína bruta e do extrato etéreo $(\mathrm{P}>0,05)$ aumentaram com a inclusão do coproduto do maracujá às dietas experimentais. Houve aumento no consumo de nitrogênio, nitrogênio absorvido e excretado na urina dos animais com a adição de níveis crescentes de coproduto de maracujá às dietas. $\mathrm{O}$ coproduto do maracujá pode ser incluído em dietas para novilhas leiteiras até o nível de $36 \%$ da dieta. Palavras-chave: Comportamento ingestivo. Consumo. Digestibilidade. Passion fruit.

1 Pesquisadora, Instituto Capixaba de Pesquisa, Assistência Técnica e Extensão Rural, CPDI Norte, Linhares, ES, Brasil. E-mail: merreg5@gmail.com

2 Profa, Universidade Federal de Minas Gerais, UFMG, Escola de Veterinária, Departamento de Zootecnia, Belo Horizonte, MG, Brasil.E-mail: saliba@vet.ufmg.br

3 Prof., Universidade Federal de Viçosa, UFV, Campus Florestal, Florestal, MG, Brasil. E-mail: geraldobarbosa@yahoo.com

4 Drs. em Zootecnia, UFMG, Escola de Veterinária, Departamento de Zootecnia, Belo Horizonte, MG, Brasil. E-mail: aguiar. filipe@gmail.com; mota_cecilia@yahoo.com.br; natydressa2009@hotmail.com; talutema@yahoo.com.br

5 Prof., Universidade Federal Rural de Pernambuco, UFRPE, Programa de Pós-Graduação em Biometria e Estatística Aplicada, Recife, PE, Brasil. E-mail: guirocham@gmail.com

* Author for correspondence 


\section{Introduction}

Brazil is the third largest fruit producer in the world, with a production volume of 43 million tons. Of this total, $47 \%$ are destined for the agroindustrial system and 53\% are sold as fresh fruit (IBRAF, 2013). Passion fruit (Passiflora edulis) is a tropical plant with wide geographic distribution. Brazil is the largest producer of this plant, with an approximate national yield of 554,598 t. hacorresponding to an average yield of 13.5 t. ha ${ }^{-1}$ per state (IBGE, 2017). Espírito Santo stands out in passion fruit growing as the sixth biggest producing state, with an average yield of 19.6 t. ha ${ }^{-1}$.

In the industrial passion fruit juice-making process, the peel, pulp and seeds are generated as by-products, which correspond to 65 to $70 \%$ of the fruit's weight (ROGÉRIO, et al., 2009). Alves et al. (2015) stated that the peel of passion fruit is rich in pectin and minerals and its seeds are an oil source with great potential for use in animal feeding. Pectin is associated with the cell wall and is not linked to lignified portions, providing a rumen digestibility of 90 to $100 \%$ (VAN SOEST, 1994).

The by-products generated in the industrial processing of the fruit for the making of juices and pulps often do not have a defined market for their sale (JOBIM et al., 2006), and, as such, they can be alternatively used in the feeding of ruminants. However, according to Figueiredo et al. (2015), one must primarily evaluate the cost/benefit of this use, since practical implications are required, involving transport costs, need for a drying area, management of drying uniformity (layers of up to $5 \mathrm{~cm}$ ) and control of spoilage and proliferation of pests.

Research has shown that, at appropriate levels, these by-products can substitute for roughage ingredients and even traditional concentrate feedstuffs such as corn and soybean meal (ROGÉRIO et al., 2009). They can also be used in the ensiling of grasses with great results (CRUZ et al., 2011; ALVES et al., 2015; BONFÁ et al., 2015; LIRA JÚNIOR et al., 2018).
According to Valadares Filho et al. (2006), the passion fruit by-product has the following nutritional characteristics: $85.90 \%$ dry matter (DM), 12.91\% crude protein (CP), 4.49\% ether extract (EE), 56.65\% neutral detergent fiber (NDF), $46.53 \%$ acid detergent fiber (ADF), $17.57 \%$ lignin, $54.91 \%$ total digestible nutrients (TDN) and $24.98 \%$ pectin. Therefore, it can be used in animal diets as a substitute for roughage feedstuffs, as a non-roughage fiber source. However, in evaluating the nutritional value of the feedstuff to determine whether its inclusion in the diet is recommended, additional information is necessary besides its chemical composition, e.g. the adequate inclusion level and effects on feed intake, digestibility and production performance (FERREIRA et al., 2010). This is because unique characteristics in chemical composition, form of supply, availability and cost may lead to differences in the potential of use of this ingredient in ruminant nutrition.

The present study proposes to examine the influence of including a passion fruit by-product as a partial substitute for Tifton 85 (Cynodon $s p$ ) hay in the diet on the intake, apparent nutrient digestibility, nitrogen and energy balance and feeding behavior of dairy heifers.

\section{Material and Methods}

The experiment took place in 2013, at the Center for Agricultural Teaching and Development of Florestal (CEDAF), located in Florestal - MG, Brazil. Sixteen Holstein $\times$ Zebu crossbred heifers with an average weight of $363.00 \pm 27.70 \mathrm{~kg}$ were the test individuals. Heifers were weighed, dewormed and housed individually in stalls with cemented floors where they were assigned at random to four treatments in a completely randomized design with four replicates. The experimental treatments consisted of diets in which a passion fruit by-product (PFB) was included at $0,12,24$, or $36 \%$ (dry matter basis) as a substitute for Tifton 85 bermuda grass (Cynodon sp) hay. 
The chemical composition of the ingredients and chemical composition of each diet are described used in the experimental diets and the ingredients in Tables 1 and 2, respectively.

Table 1. Chemical composition (\%) and gross energy levels $\left(\mathrm{Kcal} \mathrm{g}^{-1}\right)$ of the ingredients of the diets supplied during the experiment, on a dry matter basis.

\begin{tabular}{lccc}
\hline Nutrient & Tifton 85 hay & Corn meal & Passion fruit by-product \\
\hline Dry matter (\% as is) & 91.91 & 87.00 & 31.00 \\
Mineral matter & 6.01 & 1.60 & 9.71 \\
Crude protein & 5.50 & 9.10 & 13.55 \\
Neutral detergent fiber & 79.42 & 8.30 & 60.36 \\
Acid detergent fiber & 39.76 & 3.51 & 49.27 \\
Total carbohydrates & 85.98 & 85.90 & 64.34 \\
Non-fibrous carbohydrates & 14.84 & 86.35 & 17.78 \\
Lignin & 5.08 & 1.34 & 21.89 \\
NDIN ${ }^{*}$ Total N & 38.64 & 5.95 & 14.30 \\
ADIN $/$ Total N & 15.91 & 10.99 & 10.61 \\
Ether extract & 1.41 & 3.75 & 12.40 \\
Gross energy & 4.01 & 4.73 & 4.68 \\
IVDMD & 56.70 & 89.14 & 53.48 \\
TDN* & 57.74 & 83.55 & 53.32 \\
\hline
\end{tabular}

*NDIN = neutral detergent insoluble nitrogen; ADIN $=$ acid detergent insoluble nitrogen; IVDMD $=$ in vitro dry matter digestibility. TDN $=$ total digestible nutrients, estimated according to Cappelle et al. (2001).

Table 2. Centesimal (\%) and chemical compositions and average gross energy content ( $\left.\mathrm{Kcal} \mathrm{g}^{-1}\right)$ of diets containing increasing levels of passion fruit by-product, on a dry matter basis.

\begin{tabular}{|c|c|c|c|c|}
\hline \multirow{3}{*}{ Ingredient } & \multicolumn{4}{|c|}{ Experimental diet } \\
\hline & $0 \%$ & $12 \%$ & $24 \%$ & $36 \%$ \\
\hline & \multicolumn{4}{|c|}{ Centesimal composition } \\
\hline Tifton 85 bermuda grass hay & 79.00 & 70.00 & 56.00 & 44.00 \\
\hline Corn meal & 18.00 & 15.00 & 17.00 & 17.00 \\
\hline Passion fruit by-product & 0.00 & 12.00 & 24.00 & 36.00 \\
\hline Urea + ammonium sulfate & 1.00 & 1.00 & 1.00 & 1.00 \\
\hline Vitamin/mineral supplement & 2.00 & 2.00 & 2.00 & 2.00 \\
\hline Total & 100.00 & 100.00 & 100.00 & 100.00 \\
\hline \multicolumn{5}{|c|}{ Chemical composition of the diets } \\
\hline Dry matter & 88.27 & 81.10 & 73.70 & 66.30 \\
\hline Mineral matter & 4.11 & 4.79 & 5.31 & 5.90 \\
\hline Crude protein & 9.10 & 10.00 & 11.10 & 12.10 \\
\hline Neutral detergent fiber & 67.04 & 66.51 & 62.64 & 60.10 \\
\hline Acid detergent fiber & 33.48 & 35.55 & 35.70 & 36.62 \\
\hline Non-fibrous carbohydrates & 25.84 & 24.27 & 25.97 & 26.36 \\
\hline Lignin & 4.25 & 6.38 & 8.33 & 10.34 \\
\hline
\end{tabular}


continuation

\begin{tabular}{lcccc} 
Neutral detergent insoluble nitrogen & 0.29 & 0.28 & 0.28 & 0.27 \\
Neutral detergent insoluble nitrogen/Total N & 31.76 & 29.81 & 27.55 & 25.28 \\
Acid detergent insoluble nitrogen & 0.15 & 0.16 & 0.17 & 0.18 \\
Acid detergent insoluble nitrogen/Total N & 15.29 & 14.86 & 14.43 & 14.00 \\
Ether extract & 1.57 & 2.84 & 4.23 & 5.58 \\
Gross energy & 3.81 & 3.86 & 3.91 & 3.96 \\
Total digestible nutrients & 51.12 & 54.30 & 54.09 & 63.18 \\
\hline
\end{tabular}

Diets were offered in two equal meals, which were supplied at $07 \mathrm{~h} 00$ and $16 \mathrm{~h} 00$. Orts were harvested daily in the morning and weighed; the amount of feed to be supplied was based on this value plus the quantity necessary so that the orts would remain at $10 \%$. The experimental period was 17 days, consisting of 12 days dedicated for the animals to acclimate to the diets, management and facilities and five days for the sampling of feed, orts, feces and urine. Feeding behavior observations were conducted over a $24 \mathrm{~h} 00$ period.

The agro-industrial passion fruit (Passiflora edulis) by-product (PFB) was obtained from the Trop Frutas company, located in Linhares - ES, Brazil. It was composed of the peel and seeds after juice extraction, which were dried in the sun and ground, chopped together with the hay through a stationary chopper to a particle size of $2 \mathrm{~cm}$ and supplied to the animals.

Feed intake was measured as the difference in weight between the supplied feed and orts. Samples of feed and orts were harvested per treatment and per animal for chemical analyses. To measure digestibility, feces were harvested daily from the floor of each stall and weighed twice daily. After weighing, composite sub-samples representing approximately $10 \%$ of the total per animal were collected and packed in plastic bags that were then frozen at $-10{ }^{\circ} \mathrm{C}$ for laboratory analyses.

Urine was collected by the spot method on the last day of each collection period, 4h00 after feeding, during spontaneous urination. The urinary creatinine concentration was estimated using commercial kits (Labtest). The daily urine volume was estimated from the average creatinine excretion (obtained in $\mathrm{mg} \mathrm{kg}^{-1} \mathrm{LW} \mathrm{day}{ }^{-1}$ ) and the creatinine concentration $\left(\mathrm{mg} \mathrm{L}^{-1}\right)$ in the spot sample.

Laboratory analyses were carried out in the Animal Nutrition Laboratory at the Veterinary School at UFMG, in Belo Horizonte - MG, Brazil. Samples of feeds, orts and feces were thawed at room temperature, pre-dried in a forced-air oven at $55^{\circ} \mathrm{C}$ for $72 \mathrm{~h} 00$ and then ground to $1-\mathrm{mm}$ particles in a Wiley mill. Concentrations of dry matter (DM), organic matter $(\mathrm{OM})$, crude protein $(\mathrm{CP})$ and Ether Extract (EE) were determined according to the methodology recommended by Silva and Queiroz (2002) and Detmann et al. (2012). The neutral detergent fiber (NDF), acid detergent fiber (ADF), lignin, acid detergent insoluble nitrogen (ADIN) and neutral detergent insoluble nitrogen (NDIN) contents of the samples were determined following Van Soest et al. (1991), using an Ankon Fiber Analyzer.

Total carbohydrates (TC) were calculated as proposed by Sniffen et al. (1992), by the following equation:

$$
\mathrm{TC}=100-(\% \mathrm{CP}+\% \mathrm{EE}+\% \mathrm{ash})
$$

Total digestible nutrients (TDN) were calculated by the following equation proposed by Weiss (1999):

$\mathrm{TDN}=\mathrm{DCP}+\mathrm{DNFC}+\mathrm{DNDFap}+\mathrm{DEE} \times 2.25$

where DCP, DNFC, DNDFap and DEE correspond to the digestible fractions of $\mathrm{CP}$, non- 
fibrous carbohydrates, NDF corrected for ash and protein and EE, respectively. Non-fibrous carbohydrates (NFC) were calculated using the equation recommended by Hall (2000) for feedstuffs containing urea, as it was present in the diet:

$$
\begin{gathered}
\mathrm{NFC}=100-[(\% \mathrm{CP}-(\% \mathrm{CPurea}+\% \text { urea }))+ \\
\% \mathrm{NDFap}+\% \mathrm{EE}+\% \mathrm{ash}]
\end{gathered}
$$

where CPurea and NDFap correspond to the CP content of urea and to NDF corrected for ash and protein, respectively. To estimate the total digestible nutrients (TDN) in the feedstuffs separately, equations proposed by Cappelle et al. (2001) were used for roughage $(\mathrm{TDN}=10.43+0.8019 \times \mathrm{DDM}$ $\left.\left(\mathrm{r}^{2}=0.89 ; \mathrm{P}<0.01\right)\right)$ and concentrate $(\mathrm{TDN}=9.6134$ $\left.+0.8294 \times \operatorname{DDM}\left(\mathrm{r}^{2}=0.98 ; \mathrm{P}<0.01\right)\right)$ feedstuffs.

The apparent digestibility coefficients were determined from intake and fecal production data. The apparent digestibility values of the nutrients (DM, CP, EE, NDF, ADF and TC) were obtained as proposed by Silva and Leão (1979), by the following formula:

Apparent digestibility $(\%)=(($ Nutrient intake Nutrient excreted in the feces*100)/ Nutrient intake).

The gross energy content of the samples of feed, orts, feces and urine was determined using an adiabatic calorimeter (PARR 2081). The metabolizable energy (ME) content was calculated using the formulae proposed by Blaxter and Clapperton (1965):

Digestible Energy $(\mathrm{DE})=$ Gross energy $(\mathrm{GE})$ intake - GE excreted in the feces

$$
\mathrm{ME}=\mathrm{DE}-\mathrm{GE} \text { from urine }+ \text { gases }
$$

Methane production was estimated by the following equation:

$$
\mathrm{Cm}=0.67+0.062 \mathrm{D}
$$

where $\mathrm{Cm}=$ methane production in Kcal per $100 \mathrm{Kcal}$ of consumed energy; and D = apparent digestibility of the GE of the feedstuff.
Nitrogenous compounds were calculated based on $\mathrm{N}$ intake and excreted nitrogen, as absorbed $\mathrm{N}$ ( $\mathrm{g}$ day $^{-1}$ ) and $\mathrm{N}$ nitrogen $\left(\mathrm{g} \mathrm{day}^{-1}\right)$, using the following formulae:

$$
\text { Absorbed } \mathrm{N}=\mathrm{N} \text { intake }-\mathrm{N} \text { feces }
$$

$$
\text { Retained } \mathrm{N}=\mathrm{N} \text { intake }-(\mathrm{N} \text { feces }+\mathrm{N} \text { urine })
$$

To analyze the animals' feeding behavior, four trained persons took turns observing the heifers. The observers were positioned so as not to disturb the animals. Feeding behavior was evaluated over $24 \mathrm{~h} 00$, at 10 -min intervals, by observing the idling, rumination, feeding and chewing activities. The average number of chews per ruminated cud and the time taken to chew each ruminated cud were obtained in three $2 \mathrm{~h} 00$ periods ( $9 \mathrm{~h} 00$ to $11 \mathrm{~h} 00$, $15 \mathrm{~h} 00$ to $17 \mathrm{~h} 00$ and $19 \mathrm{~h} 00$ to $21 \mathrm{~h} 00$ ), using a digital timer. The following formulae proposed by Burguer et al. (2000) were used for the analysis of feeding behavior-related parameters:

$$
\begin{gathered}
\mathrm{TCT}=\mathrm{FT}+\mathrm{RT} \\
\mathrm{NRC}=\mathrm{RT} / \mathrm{TCC} \\
\mathrm{RCD}=\mathrm{NRC} \times \mathrm{NCC} \\
\mathrm{RE}_{\mathrm{DM}}=\mathrm{DMI} / \mathrm{RT} \\
\mathrm{FE}_{\mathrm{DM}}=\mathrm{DMI} / \mathrm{FT}
\end{gathered}
$$

where TCT (h day ${ }^{-1}$ ): total chewing time; FT (h day $^{-1}$ ): feeding time; RT (h day ${ }^{-1}$ ): rumination time; NRC ( $\mathrm{n}$ day $^{-1}$ ): number of ruminated cuds; TCC $\left(\mathrm{s} \mathrm{cud}^{-1}\right)$ : time taken to chew each ruminated cud (POLLI et al., 1996); RCD: number cud chews per day $\left(\mathrm{n} \mathrm{day}^{-1}\right)$; NCC $\left(\mathrm{n} \mathrm{cud}^{-1}\right)$ : number of chews per ruminated cud; $\mathrm{RE}_{\mathrm{DM}}\left(\mathrm{g} \mathrm{DM}\right.$ ruminated $\left.\mathrm{h}^{-1}\right)$ : rumination efficiency; $\mathrm{FE}_{\mathrm{DM}}\left(\mathrm{g} \mathrm{DM}\right.$ intake $\left.\mathrm{h}^{-1}\right)$ : feed efficiency; and DMI (g): dry matter intake.

The data were subjected to variance and regression analyses as a function of passion fruit by-product inclusion in the diets (0, 8, 16 and 24\%), using SISVAR software (FERREIRA, 2014). Means were compared by the Student-Newman-Keuls test at the $5 \%$ probability level. The present study was conducted in compliance with ethical standards, 
after approval by the Ethics Committee on Animal Experimentation (approval no. 225/2015).

\section{Results and Discussion}

The intakes of dry matter DM (DMI), OM, NDF, $\mathrm{ADF}$ and $\mathrm{TC}$ were not affected by the inclusion of
PFB $(\mathrm{P}>0.05)$ in the experimental diets, averaging $89.94,84.73,59.92,32.19,81.10$ grams per unit of metabolic size $\left(\mathrm{g} \mathrm{UMS}^{-1}\right)$, respectively (Table 3$)$. According to the NRC (2001), the recommended DMI for this animal category in UMS is $94.60 \mathrm{~g}$. In this study, this value was only attained at the PFB inclusion levels of $12 \%$ and $36 \%$.

Table 3. Mean values for the daily intake $\left(\mathrm{kg} d a y^{-1}, \%\right.$ live weight $(\% \mathrm{LW})$, and units of metabolic size $\left.\left(\mathrm{g} \mathrm{UMS}^{-1}\right)\right)$ of chemical components and regression equations according to the inclusion level of passion fruit by-product in diets for dairy heifers.

\begin{tabular}{|c|c|c|c|c|c|c|c|}
\hline \multirow{3}{*}{ Variable } & \multicolumn{4}{|c|}{ Treatment } & \multirow[b]{3}{*}{ Equation } & \multirow[b]{3}{*}{$\mathrm{CV}$} & \multirow[b]{3}{*}{ SEM } \\
\hline & $0 \%$ & $12 \%$ & $24 \%$ & $36 \%$ & & & \\
\hline & \multicolumn{4}{|c|}{ Intake, $\mathrm{kg} \mathrm{day}^{-1}$} & & & \\
\hline Dry matter & 7.05 & 7.84 & 7.70 & 7.90 & $\mathrm{Y}=\mathrm{NS}$ & 13.26 & 0.25 \\
\hline Organic matter & 6.75 & 7.45 & 6.67 & 7.42 & $\mathrm{Y}=\mathrm{NS}$ & 14.04 & 0.23 \\
\hline Crude protein & $0.66 \mathrm{~b}$ & $0.78 \mathrm{ab}$ & $0.76 \mathrm{ab}$ & $0.93 \mathrm{a}$ & $\mathrm{Y}={ }^{*}$ & 11.82 & 0.03 \\
\hline Ether extract & $0.11 \mathrm{c}$ & $0.22 b$ & $0.27 \mathrm{~b}$ & $0.43 \mathrm{a}$ & $\mathrm{Y}={ }^{*}$ & 19.92 & 0.03 \\
\hline Neutral detergent fiber & 4.91 & 5.38 & 4.63 & 4.96 & $\mathrm{Y}=\mathrm{NS}$ & 13.13 & 0.16 \\
\hline Acid detergent fiber & 2.45 & 2.86 & 2.56 & 2.99 & $\mathrm{Y}=\mathrm{NS}$ & 16.13 & 0.10 \\
\hline Non-fibrous carbohydrates & 1.78 & 1.87 & 1.78 & 1.91 & $\mathrm{Y}=\mathrm{NS}$ & 13.14 & 0.06 \\
\hline Total carbohydrates & 6.61 & 7.19 & 6.43 & 6.33 & $\mathrm{Y}=\mathrm{NS}$ & 15.79 & 0.25 \\
\hline \multicolumn{8}{|c|}{ Intake, \%LW } \\
\hline Dry matter & 1.95 & 2.18 & 1.96 & 2.17 & $\mathrm{Y}=\mathrm{NS}$ & 15.93 & 0.08 \\
\hline Organic matter & 1.85 & 2.06 & 1.83 & 2.04 & $\mathrm{Y}=\mathrm{NS}$ & 16.67 & 0.08 \\
\hline Crude protein & $0.18 b$ & $0.22 \mathrm{ab}$ & $0.21 \mathrm{ab}$ & $0.26 \mathrm{a}$ & $\mathrm{Y}={ }^{*}$ & 14.51 & 0.01 \\
\hline Ether extract & $0.03 \mathrm{c}$ & $0.06 \mathrm{ab}$ & $0.07 \mathrm{~b}$ & $0.12 \mathrm{a}$ & $\mathrm{Y}={ }^{*}$ & 23.60 & 0.01 \\
\hline Neutral detergent fiber & 1.36 & 1.50 & 1.28 & 1.36 & $\mathrm{Y}=\mathrm{NS}$ & 15.90 & 0.05 \\
\hline Acid detergent fiber & 0.67 & 0.77 & 0.77 & 0.72 & $\mathrm{Y}=\mathrm{NS}$ & 18.24 & 0.03 \\
\hline Total carbohydrates & 1.77 & 1.99 & 1.92 & 1.77 & $\mathrm{Y}=\mathrm{NS}$ & 18.04 & 0.08 \\
\hline \multicolumn{8}{|c|}{ Intake, $\mathrm{g} \mathrm{UMS}^{-1}$} \\
\hline Dry matter & 85.07 & 94.85 & 85.22 & 94.60 & $\mathrm{Y}=\mathrm{NS}$ & 14.86 & 3.23 \\
\hline Organic matter & 80.45 & 89.47 & 79.74 & 89.25 & $\mathrm{Y}=\mathrm{NS}$ & 15.63 & 3.26 \\
\hline Crude protein & $7.95 \mathrm{c}$ & $9.44 \mathrm{ab}$ & $9.24 \mathrm{ab}$ & $11.16 \mathrm{a}$ & $\mathrm{Y}={ }^{*}$ & 13.79 & 0.41 \\
\hline Ether extract & $1.36 \mathrm{c}$ & $2.72 b$ & $3.36 \mathrm{~b}$ & $5.25 \mathrm{a}$ & $\mathrm{Y}={ }^{*}$ & 21.14 & 0.39 \\
\hline Neutral detergent fiber & 59.21 & 65.08 & 55.91 & 59.46 & $\mathrm{Y}=\mathrm{NS}$ & 14.76 & 2.15 \\
\hline Acid detergent fiber & 29.91 & 33.65 & 33.55 & 31.66 & $\mathrm{Y}=\mathrm{NS}$ & 17.21 & 1.32 \\
\hline Total carbohydrates & 76.78 & 86.67 & 83.52 & 77.41 & $\mathrm{Y}=\mathrm{NS}$ & 16.98 & 3.26 \\
\hline
\end{tabular}

* Means followed by different letters in the rows differ statistically according to the $\mathrm{SNK}$ test $(\mathrm{P}<0.05)$; $\mathrm{CV}=$ coefficient of variation; SEM = standard error of the mean. 
Table 4. Regression equations for the intakes of crude protein and ether extract in $\mathrm{kg} \mathrm{day}^{-1}, \%$ live weight, and units of metabolic size $\left(\mathrm{g} \mathrm{UMS}{ }^{-1}\right)$.

\begin{tabular}{ccc}
\hline Crude protein intake & Equation & $\mathrm{R}^{2}$ \\
\hline $\mathrm{kg} \mathrm{day}^{-1}$ & $\mathrm{Y}=0.66+0.0067 \mathrm{X}$ & 84.94 \\
$\% \mathrm{LW}$ & $\mathrm{Y}=0.186 \mathrm{X}+0.183 \mathrm{X}^{2}$ & 80.76 \\
$\mathrm{~g} \mathrm{UMS}^{-1}$ & $\mathrm{Y}=8.033+0.078 \mathrm{X}$ & 85.27 \\
\hline Ether extract intake & Equation & $\mathrm{R}^{2}$ \\
\hline $\mathrm{kg} \mathrm{day}^{-1}$ & $\mathrm{Y}=0.109+0.0085 \mathrm{X}$ & 96.31 \\
$\% \mathrm{LW}^{-1}$ & $\mathrm{Y}=0.0028+0.0023 \mathrm{X}$ & 93.33 \\
$\mathrm{~g} \mathrm{UMS}^{-1}$ & $\mathrm{Y}=1.326+0.102 \mathrm{X}$ & 96.66 \\
\hline
\end{tabular}

$\mathrm{R}^{2}=$ determination coefficient.

The DM content of the experimental diets decreased with increasing PFB inclusion. This was because this PFB contains high moisture as it leaves the industry and does not dehydrate completely even after sun-drying. However, no influence was observed on DMI.

Mertens (1987) stated that DMI is inversely related to the dietary NDF content and that highfiber diets limit the intake capacity of the animal due to rumen-reticulum fill. Although the NDF content of the hay was higher than that of PFB, the hay has a good NDF-to-ADF ratio approximately 50:50, in addition to low lignin content. The NDF content $(60.36 \%)$ of PFB demonstrates the possibility of its use as a source of forage fiber in ruminant diets, which is a positive aspect for times of low forage availability and high availability of the by-product regionally. From the nutritional perspective, fiber is the slowly and incompletely digestible fraction of feedstuffs that has a filling effect on the gastrointestinal tract of animals (MERTENS, 1997). NDF values greater than $60 \%$ are negatively correlated with voluntary DM intake and with the net energy content. Even so, this fraction is very important because of the balance provided to the rumen environment from rumination. In the present study, the NDF content of all tested diets was higher than $60 \%$, although it decreased with the inclusion of PFB in the diets, (Table 1). However, this fact did not influence nutrient intake. Furthermore, Van Soest (1994) suggested that NDF intakes above 0.8 to $1.2 \%$ LW, as reported in this study, would limit DMI, yet no such effect was observed in the present experiment. In the present study, the NDF content of all evaluated diets was higher than $60 \%$.

The ADF content of PFB accounted for $80 \%$ of the NDF, which is close to the $83 \%$ found by Cruz et al. (2011), and this result was probably due to the contribution of the seeds. Acid detergent fiber is composed of cellulose and lignin, the latter of which represented only $28 \%$ of the total ADF in this case, demonstrating the potential of use of the by-product as a fiber source for ruminants.

Crude protein intake $(\mathrm{CPI})$ rose $(\mathrm{P}<0.05)$ with the addition of PFB up to the inclusion level of $36 \%$, when this variable averaged $783.0 \mathrm{~g} \mathrm{day}^{-1}$. The regression equation for CPI revealed a linear increase in $\mathrm{CP}$ content as the PFB levels added to the diets were increased, with a maximum intake of $0.9 \mathrm{~g} \mathrm{day}^{-1}$ at the highest inclusion level. Although the CP contents were similar across the experimental diets (Table 2) because they were formulated to be isoproteic, CPI was higher in the diets including PFB. This is probably a result of the uptake of this nutrient from the test ingredient, since by-products are, in general, important protein sources.

Ether extract intake $(\mathrm{EEI})$ increased $(\mathrm{P}<0.05)$ linearly with the inclusion of PFB in the diets, averaging $258.0 \mathrm{~g} \mathrm{day}^{-1}$. At the inclusion level of $36 \%$, the average EEI was $415.0 \mathrm{~g} \mathrm{day}^{-1}$, which was a consequence of the greater concentration of this nutrient in the diets (Table 4). The EE content of $12.40 \%$ found in the PFB in the present study (Table 
1) is close to the $12.20 \%$ found by Azevedo et al. (2011) but considerably higher than the 7.97\% reported by Rogério (2005) and $4.97 \%$ reported by Sena et al. (2015) and lower than the $20.60 \%$ found by Azevedo et al. (2017). According to Ferrari et al. (2004), the oil extracted from passion fruit seeds has an unsaturated fatty acid content greater than $87 \%$. These fatty acids consist majorly of linoleic acid, which, when in excess, is toxic to ruminal bacteria. Despite increasing, the EE contents of the diets including PFB did not exceed $7 \%$ of the DM, which could cause a depression of the rumen microbiota, mainly in the population of cellulolytic microorganisms, resulting in impaired digestion of fiber (NRC, 2001). The highest concentration of EE obtained with the maximum inclusion of this by-product is likely due to the contribution of the seeds, which may represent around $24.50 \%$ (DM basis), as described by Togashi et al. (2007). Therefore, the diet with the PFB inclusion level of $36 \%$ provided the highest EE intake, since its EE content was $5.57 \%$ ( $\mathrm{DM}$ basis), differing $(\mathrm{P}<0.05)$ from the diets without the ingredient or with lower levels of it.

The presence of seeds also increased the lignin content of the diet, although it did not compromise nutrient intake by the animals. This increasing EE concentration in the diets observed with PFB inclusion demonstrates the high availability of its lipid fraction. Despite not having provided a great increase in the dietary EE content, the lipid fraction was sufficient to increase EEI, enabling the use of PFB as an energy component in ruminant diets. Azevedo et al. (2011) stated that PFB has the potential to partially substitute for roughages in ruminant diets as long as the EE levels are observed.

There were no significant differences for the digestibility coefficients of the analyzed nutrients across the experimental diets (Table 5). The only exception was EE, whose digestibility increased with the PFB levels, which is explained by the higher concentration of this ingredient in the diets (Table 2). The low apparent digestibility values of DM $(51.12 \%$, on average) and fibrous fractions $(\mathrm{NDF}=43.43 \%, \mathrm{ADF}=37.86 \%$ and $\mathrm{TC}=53.93 \%)$ observed in this study can be attributed to the roughage-to-concentrate ratio of 80:20 in the diets. Despite the elevated amount of lignin (10.34\%) in the experimental diet containing $36 \% \mathrm{PFB}$, the digestibility of $\mathrm{CP}$ and ADF did not decrease. The CP content of PFB (13.55\%), which is higher than that of most medium-quality roughages, and the ADIN/Total N ratio of $10.99 \%$, which is lower than that of Tifton 85 bermuda grass $(15.91 \%)$, coupled with the right amount of rumen-fermentable carbohydrates, indicate that this by-product can contribute to meeting the requirement of production animals.

Table 5. Mean values (\%) of apparent digestibility coefficients of the nutrients of diets containing increasing levels of passion fruit by-product supplied to dairy heifers.

\begin{tabular}{lccccccc}
\hline \multirow{2}{*}{ Variable } & \multicolumn{7}{c}{ Treatment } \\
\cline { 2 - 8 } & $0 \%$ & $12 \%$ & $24 \%$ & $36 \%$ & Reg. equation & CV & SEM \\
\hline DDM & 48.70 & 54.55 & 52.10 & 55.65 & $\mathrm{Y}=\mathrm{NS}$ & 13.90 & 1.77 \\
DCP & 64.09 & 66.62 & 63.23 & 71.29 & $\mathrm{Y}=\mathrm{NS}$ & 8.21 & 1.46 \\
DEE & $55.34 \mathrm{~b}$ & $66.36 \mathrm{ab}$ & $75.26 \mathrm{a}$ & $73.14 \mathrm{a}$ & $\mathrm{Y}=*$ & 9.68 & 2.48 \\
DNDF & 41.20 & 44.84 & 39.69 & 48.00 & $\mathrm{Y}=\mathrm{NS}$ & 20.17 & 2.13 \\
DADF & 33.96 & 38.78 & 33.85 & 44.85 & $\mathrm{Y}=\mathrm{NS}$ & 29.66 & 2.77 \\
DTC & 52.38 & 54.59 & 53.62 & 55.11 & $\mathrm{Y}=\mathrm{NS}$ & 19.35 & 2.35 \\
\hline
\end{tabular}

$* \mathrm{Y}=54.895+1.3404 \mathrm{X}-0.0228 \mathrm{X}^{2} \mathrm{R}^{2}=98.36$.

Apparent digestibility of dry matter (DDM), crude protein (DCP), ether extract (DEE), neutral detergent fiber (DNDF), acid detergent fiber (DADF), and total carbohydrates (DTC).

$\mathrm{CV}(\%)$ - coefficient of variation; SEM - standard error of the mean.

* Means followed by different letters in the rows differ statistically according to the SKN test $(\mathrm{P}<0.05)$; NS - not significant. 
Lousada Júnior et al. (2005) evaluated the nutritional value of fruit processing by-products (pineapple, acerola [Malpighia emarginata], guava, passion fruit and melon) in sheep and found mean DDM and DCP values of $59.95 \%$ and $54.35 \%$ in $\mathrm{PFB}$, respectively, which are similar to those obtained in the present study. According to those authors, the DDM of PFB was the highest among all evaluated by-products. The researchers attributed this result to the low lignin content $(9.5 \%)$ associated with the good CP content (12.4\%) of PFB when compared with that of the other by-products. Rogério (2005) also worked with sheep, feeding them diets with an average $\mathrm{CP}$ content of $13.70 \%$, and found an average DCP of $58.76 \%$, which is lower than the $66.31 \%$ found in the current study. Azevedo et al. (2011) investigated the inclusion of fresh fruit by-product (pineapple, guava, papaya, mango and passion fruit) at different inclusion levels (10 and 30\%) replacing corn in cattle diets and found an average DDM of $60.00 \%$ for both levels and average DCP values of 68.46 and $64.80 \%$, respectively, which are lower than the present values. Sena et al. (2015), in turn, found an average DCP of $59.90 \%$ in sheep diets in which $0,20,40$ and $60 \%$ of Tifton bermuda grass hay had been substituted with dried PFB.

Nitrogen balance parameters differed $(\mathrm{P}<0.05)$, with $\mathrm{N}$ intake, absorbed $\mathrm{N}$ and urinary $\mathrm{N}$ increasing as the PFB inclusion levels were elevated (Table 6). These variables averaged 125.41, 83.30 and 22.22 $\mathrm{g}_{\text {day }}{ }^{-1}$, respectively. Nitrogen intake values rose by $107 \mathrm{~g}$ day $^{-1}$ with every $1 \%$ inclusion of PFB in the diets, reaching $145 \mathrm{~g} \mathrm{day}^{-1}$ at the inclusion of $36 \%$ of the by-product. Following the response shown by CPI, nitrogen intake also increased linearly with PFB because the protein value of PFB complemented that of Tifton 85 bermuda grass hay in the diets. In the current study, all diets including PFB led to a positive $\mathrm{N}$ balance, indicating that they met the protein requirements for maintenance and gain. Nitrogen balance is important, as it can indicate a possible lack of adjustments in the amounts of nutrient or in their degradation rate, since it is the relationship between dietary protein and energy fermentations that leads to higher nitrogen balance (SILVA; LEÃO, 1979).

Table 6. Mean values of nitrogenous $(\mathrm{N})$ compounds $\left(\mathrm{g} \mathrm{day}^{-1}\right)$, nitrogen balance $\left(\mathrm{g}\right.$ day $\left.{ }^{-1}\right)$, in heifers fed diets containing increasing levels of passion fruit by-product.

\begin{tabular}{lccccccc}
\hline \multirow{2}{*}{ Variable } & \multicolumn{7}{c}{ Treatment } \\
\cline { 2 - 8 } & $0 \%$ & $12 \%$ & $24 \%$ & $36 \%$ & $\mathrm{CV}$ & Regression equation & SEM \\
\hline $\mathrm{N}$ intake & $105.41 \mathrm{~b}$ & $124.84 \mathrm{ab}$ & $122.27 \mathrm{ab}$ & $149.12 \mathrm{a}$ & 11.93 & $*$ & 5.22 \\
Fecal N & 37.92 & 42.11 & 45.17 & 43.24 & 23.63 & $\mathrm{Y}=\mathrm{NS}$ & 2.37 \\
Absorbed N & $67.48 \mathrm{~b}$ & $82.73 \mathrm{ab}$ & $77.10 \mathrm{ab}$ & $105.88 \mathrm{a}$ & 11.60 & $*$ & 4.25 \\
Urinary N & $13.89 \mathrm{c}$ & $25.69 \mathrm{ab}$ & $20.19 \mathrm{ab}$ & $29.12 \mathrm{a}$ & 26.93 & $*$ & 2.00 \\
$\mathrm{~N}$ balance & 53.59 & 57.04 & 56.91 & 76.76 & 19.82 & $\mathrm{Y}=\mathrm{NS}$ & 3.59 \\
Retained N/N intake (\%) & 50.84 & 45.70 & 46.54 & 51.48 & 15.88 & $\mathrm{Y}=\mathrm{NS}$ & 1.67 \\
\hline
\end{tabular}

$\mathrm{N}$ intake: $\mathrm{Y}=106.13+1.071 \mathrm{X}, \mathrm{R}^{2}=85.04 ;$ Absorbed $\mathrm{N}: \mathrm{Y}=66.862+0.9131 \mathrm{X} \mathrm{R}^{2}=75.14$; Urinary N: $\mathrm{Y}=16.194+0.3334 \mathrm{X} ; \mathrm{R}^{2}=60.65$. $\mathrm{CV}(\%)$ - coefficient of variation; SEM - standard error of the mean.

*Means followed by different letters in the rows differ statistically according to the SKN test $(\mathrm{P}<0.05)$.

The metabolizable energy content of the experimental diets with $24 \%$ inclusion of the PFB was below the $14.70 \mathrm{Mcal}^{\mathrm{day}^{-1}}$ recommended by the NRC (2001) for animals of a similar category.
In the current study, this value was only attained at the PFB inclusion level of $36 \%$ (Table 7). Even so, the animals did not show weight loss at the end of the experimental period, which was a consequence 
of the positive contribution of PFB in supplying NFC, soluble proteins, minerals, vitamins and EE to the diets, improving the ruminal environment.
The amount of ME was likely the prevalent factor for the elimination of nitrogen in urea, as a body mechanism to eliminate its excess.

Table 7. Gross energy (GE) intake, digestible gross energy, gross energy digestibility, and metabolizable energy (Mcal day $^{-1}$ ) of the experimental diets.

\begin{tabular}{lcccccc}
\hline \multirow{2}{*}{ Variable } & \multicolumn{7}{c}{ Treatment } \\
\cline { 2 - 7 } & $0 \%$ & $12 \%$ & $24 \%$ & $36 \%$ & CV & SEM \\
\hline GE intake & 27.75 & 31.57 & 28.80 & 33.00 & 13.42 & 1.06 \\
Digestible GE & 13.08 & 15.53 & 14.19 & 17.88 & 17.04 & 0.74 \\
GE digestibility & 47.23 & 49.52 & 49.35 & 54.38 & 13.14 & 1.62 \\
ME & 10.13 & 12.76 & 12.77 & 14.71 & 22.55 & 0.76 \\
\hline
\end{tabular}

CV (\%) - coefficient of variation; SEM - standard error of the mean.

Van Soest (1994) stated that, for the rumen environment to be optimized, there must be synergism between protein degradation, the ammonia level and carbohydrate fermentation. Ruminal efficiency is determined by the energy-toprotein ratio of the diet, and the amount of microbial protein synthesized in the rumen is equal to the amount of rumen-degradable protein, calculated as $13 \%$ of the TDN intake. In the present study, based on this ratio, we obtained $6.65 \%, 7.06 \%, 7.03 \%$ and $8.21 \%$ of synthesized microbial protein at the respective PFB inclusion levels, which are adequate for all experimental diets as verified by the $\mathrm{CP}$ and ADIN values (Table 2).

The PFB inclusion levels did not influence the feeding behavior of the animals (Table 8), which is probably because this by-product has characteristics that maintain ruminal activity unchanged; as such, it can substitute for the forage-derived roughage without compromising the ruminal metabolism.

The feeding behavior of an animal may provide important information about the quality of the diet it is offered. Increasing amounts of fiber in the diet stimulate the chewing activity and reduce acid production, which usually occurs when by-products (non-forage fiber sources) replace roughages in ruminant diets. In the present study,
PFB inclusion did not influence the intakes of DM and NDF or feeding behavior parameters. A possible explanation for this finding is the fact that the diets had the same roughage-toconcentrate ratio and fibrous fraction contents, which likely did not influence digestibility.

Macedo et al. (2007) evaluated the influence of orange bagasse substituting for sorghum silage on sheep fed a sorghum silage-only diet and found feeding and idling times of 6.04 and $7.69 \mathrm{~h} \mathrm{day}^{-1}$, which are similar values to that obtained in this study for the diets with Tifton 85 bermuda grass hay $\left(7.05 \mathrm{~h} \mathrm{day}^{-1}\right)$. This was probably because the NDF content of the sorghum silage-only $(70.78 \%$; DM basis) was similar to the NDF content of the diet with Tifton 85 bermuda grass hay (67.04\%). Pereira et al. (2007) evaluated the feeding behavior of dairy heifers fed diets with different fiber contents and found a longer total chewing time when the animals received a diet with a higher NDF content $(60 \%)$, showing that the chemical and physical quality of roughages is directly related to behavioral aspects of ruminants. In the present study, the NDF content of Tifton 85 bermuda grass was $75.42 \%$, whereas that of PFB was $60.36 \%$. Both had the same effectiveness, which was shown by the lack of significant differences across the diets for feeding behavior parameters. 
Table 8. Parameters of the feeding behavior of heifers fed diets containing increasing levels of passion fruit byproduct.

\begin{tabular}{|c|c|c|c|c|c|c|}
\hline \multicolumn{7}{|c|}{ Treatment } \\
\hline Parameter & $0 \%$ & $12 \%$ & $24 \%$ & $36 \%$ & $\mathrm{CV}$ & SEM \\
\hline DMI (\% LW) & 1.95 & 2.18 & 1.96 & 2.17 & 15.93 & 0.08 \\
\hline NDFI $\left(\mathrm{kg} \mathrm{day}^{-1}\right)$ & 4.91 & 5.38 & 4.63 & 4.96 & 13.13 & 0.05 \\
\hline FT $\left(\right.$ h day $\left.{ }^{-1}\right)$ & 5.96 & 5.00 & 5.63 & 5.50 & 12.91 & 0.18 \\
\hline IT $\left(\mathrm{h} \mathrm{day}^{-1}\right)$ & 7.88 & 9.96 & 9.29 & 8.92 & 16.43 & 0.38 \\
\hline RT $\left(\right.$ h day $\left.^{-1}\right)$ & 9.25 & 8.33 & 8.42 & 8.13 & 9.14 & 0.21 \\
\hline OT (h day $\left.{ }^{-1}\right)$ & 0.92 & 0.71 & 0.67 & 1.46 & 63.78 & 0.16 \\
\hline TCT $\left(\right.$ h day $\left.{ }^{-1}\right)$ & 15.21 & 13.33 & 14.04 & 13.63 & 8.66 & 0.33 \\
\hline $\mathrm{FE}\left(\mathrm{kg} \mathrm{DM} \mathrm{h}{ }^{-1}\right)$ & 1.21 & 1.57 & 1.17 & 1.45 & 17.47 & 0.39 \\
\hline $\mathrm{RE}_{\mathrm{DM}}\left(\mathrm{kg} \mathrm{DM} \mathrm{h}^{-1}\right)$ & 0.76 & 0.94 & 0.79 & 0.98 & 14.22 & 0.42 \\
\hline $\mathrm{RE}_{\mathrm{NDF}}\left(\mathrm{kg} \mathrm{NDF} \mathrm{h}^{-1}\right)$ & 0.53 & 0.64 & 0.55 & 0.61 & 11.81 & 0.82 \\
\hline NCC $\left(\right.$ n day $\left.^{-1}\right)$ & 72.14 & 62.73 & 67.81 & 64.22 & 6.98 & 0.44 \\
\hline $\mathrm{TCC}\left(\mathrm{s} \mathrm{cud}^{-1}\right)$ & 39.24 & 46.07 & 43.12 & 40.08 & 14.83 & 0.19 \\
\hline RCD $\left(\right.$ n day $\left.^{-1}\right)$ & 11.82 & 10.52 & 11.07 & 11.41 & 14.21 & 0.10 \\
\hline $\operatorname{NRC}\left(\right.$ n day $\left.^{-1}\right)$ & 853.64 & 659.27 & 752.80 & 729.53 & 15.37 & 0.32 \\
\hline
\end{tabular}

DMI (\% LW) - average dry matter intake in \% of live weight; NDFI - neutral detergent fiber intake; FT - feeding time; IT idling time; RT - rumination time; OT - time expended on other activities; TCT - total chewing time; FE - feed efficiency; $\mathrm{RE}_{\mathrm{DM}}$ - rumination efficiency in dry matter; $\mathrm{RE}_{\mathrm{NDF}}$ - rumination efficiency in neutral detergent fiber; NCC - number of chews per cud; TCC - time taken to chew each ruminated cud; RCD - number cud chews per day; NRC - number of ruminated cuds. $\mathrm{CV}(\%)$ - coefficient of variation; SEM - standard error of the mean.

The lack of effects on the feeding behavior of the animals fed diets containing increasing levels of PFB demonstrates the potential of this feedstuff, considering its palatability as well as other factors such as total chewing time, which was not changed, ranging from 13.33 to $15.21 \mathrm{~h}$ day $^{-1}$. Therefore, the forage source of fiber (Tifton 85 bermuda grass hay) can be substituted by a non-forage source of fiber such as PFB without changing the effectiveness of the diet or animal productivity.

\section{Conclusions}

Dry matter intake was not changed by the substitution of Tifton 85 bermuda grass hay by passion fruit by-product in the diets.

There was a positive effect on the intakes of crude protein and ether extract, which increased linearly with the inclusion of passion fruit by-product.
Passion fruit by-product can be used up to the level of $36 \%$ as a substitute for Tifton 85 bermuda grass in diets for dairy heifers.

\section{Acknowledgments}

The authors thank Instituto Capixaba de Pesquisa, Assistência Técnica e Extensão Rural - ES, Universidade Federal de Minas Gerais, a Central de Ensino e Desenvolvimento Agrário de Florestal - MG and TROP FRUTAS Linhares - ES for supporting the research.

This study was financed in part by the Coordenação deAperfeiçoamento de Pessoal de Nível Superior - Brasil (CAPES) - Finance Code 001 . 


\section{References}

ALVES, G. R.; FONTES, C. A. A.; PROCESSI, E. F.; FERNANDES, A. M.; OLIVEIRA, T. S.; GLORIA, L. S. Performance and digestibility of steers fed by-product of fresh passion fruit or sorghum silage, with and without concentrate supplementation. Revista Brasileira de Zootecnia, Viçosa, MG, v. 44, n. 9, p. 314-320, 2015. DOI: $10.1590 / \mathrm{S} 1806-92902015000900002$

AZEVEDO, J. A. G.; VALADARES FILHO, S. C.; PINA, D. S.; DETMANN, E.; VALADARES, R. F. D.; PEREIRA, L. G.; SOUZA, N. K. P.; SILVA, L. F. C. Consumo, digestibilidade total, produção de proteína microbiana e balanço de nitrogênio em dietas com resíduos de frutas para ruminantes. Revista Brasileira de Zootecnia, Viçosa, MG, v. 40, n. 5, p. 1052-1060, 2011. DOI: $10.1590 / \mathrm{S} 1516-35982011000500017$

AZEVEDO, J. C.; ARAUJO, S. A. C.; ROCHA, N. S.; CARDOSO, A. M.; PANTOJA, L. A.; FATURI, C.; DOMINGUES, F. N. Fruit agribusiness waste as an additive in elephant grass silage. Semina: Ciências Agrárias, Londrina, v. 38, n. 4, p. 1987-2000, 2017. DOI: $10.5433 / 1679-0359.2017 \mathrm{v} 38 \mathrm{n} 4 \mathrm{p} 1987$

BLAXTER, K. L.; CLAPPERTON, J. L. Prediction of the amount of methane produced by ruminants. British Journal Nutrition, Cambridge, v. 19, n. 1, p. 511-522, 1965. DOI: 10.1079/BJN19650046

BONFÁ, C. S.; CASTRO, G. H. F.; VILELA, S. D. J.; SANTOS, R. A.; EVANGELISTA, A. R.; JAYME, C. G.; GONÇALVES, L. C.; PIRES NETO, O. S.; BARBOSA, J. A. S. Silagem de capim-elefante adicionada de casca de maracujá. Arquivo Brasileiro de Medicina Veterinária e Zootecnia, Belo Horizonte, v. 67, n. 3, p. 801-808, 2015. DOI: $10.1590 / 1678-4162-7982$

BURGUER, P. J.; PEREIRA, J. C.; QUEIROZ, A. C.; SILVA, J. F. C.; VALADARES FILHO, S. C.; CECON, P. R.; CASALI, A. D. P. Comportamento ingestivo em bezerros holandeses alimentados com dietas contendo diferentes níveis de concentrado. Revista Brasileira de Zootecnia, Viçosa, MG, v. 29, n. 1, p. 236-242, 2000. DOI: $10.1590 / \mathrm{S} 1516-3598200000010003.1$

CAPPELLE, E. R.; VALADARES FILHO, S. C.; SILVA, J. F. C.; CECON, P. R. Estimativas do valor energético a partir de características químicas e bromatológicas dos alimentos. Revista Brasileira de Zootecnia, Viçosa, MG, v. 30 , n. 6 , p. $1837-1856,2001$. DOI: $0.1590 / \mathrm{S} 1516-$ 35982001000700022

CRUZ, B. C. C.; CRUZ, C. L. S.; PIRES, A. J. V.; ROCHA, J. B.; SANTOS, S.; BASTOS, M. P. V. Desempenho, consumo e digestibilidade de cordeiros em confinamento recebendo silagens de capim elefante com diferentes proporções de casca desidratada de maracujá. Semina: Ciências Agrárias, Londrina, v. 32, n. 4, p. $1595-$ 1604, 2011. DOI: 10.5433/1679-0359.2011v32n4p1595

DETMANN, E.; SOUZA, M. A.; VALADARES FILHO, S. C.; QUEIROZ, A. C.; BERCHIELLI, T. T.; SALIBA, E. O. S.; CABRAL, L. S.; PINA, D. S.; LADEIRA, M. M.; AZEVEDO, J. A. G. Métodos para análise de alimentos. Visconde do Rio Branco: Instituto Nacional de Ciência e Tecnologia de Ciência Animal-INCT, Suprema, 2012. $214 \mathrm{p}$.

FERRARI, R. A.; COLUSSI, F.; AYUB, R. A. Caracterização de subprodutos da industrialização do maracujá-aproveitamento das sementes. Revista Brasileira de Fruticultura, Jaboticabal, v. 26, n. 1, p. 101102, 2004. DOI: 10.1590/S0100-29452004000100027

FERREIRA, A. C. H.; NEIVA, J. N. M.; RODRIGUEZ, N. M.; LOPES, F. C. F.; LÔBO, R. N. B. Consumo e digestibilidade de silagens de capim-elefante com diferentes níveis de subproduto da agroindústria da acerola. Revista Ciência Agronômica, Fortaleza, v. 41, n. 4, p. 693-701, 2010. DOI: 10.1590/S180666902010000400025

FERREIRA, D. F. Sisvar: a guide for its Bootstrap procedures in multiple comparisons. Ciência $e$ Agrotecnologia, Lavras, v. 38, n. 2, p. 109-112, 2014. DOI: $10.1590 / \mathrm{S} 1413-70542014000200001$

FIGUEIREDO, D. M.; ALMEIDA, J. C. S.; BOARI, C. A.; PAIXÃO, M. L.; SENA, J. A. B.; BARBOSA, J. L.; ORTÊNCIO, M. O.; MOREIRA, K. F. Desempenho, medidas corporais, rendimentos de carcaça e cortes, e qualidade de carne em cordeiros alimentados com resíduos da agroindústria processadora de frutas. Semina: Ciências Agrárias, Londrina, v. 36, n. 1, p. 541-556, 2015. DOI: $10.5433 / 1679-0359.2015 v 36 n 1 \mathrm{p} 541$

HALL, M. B. Calculation of non-structural carbohydrate content of feeds that contain non-protein nitrogen. Florida: University of Florida, 2000. A-25 p. (Bulletin, 339).

INSTITUTO BRASILEIRO DE FRUTAS - IBRAF. Panorama da cadeia produtiva de frutas em 2012 e projeções para 2013. São Paulo: IBRAF, 2013. 127 p. Disponível em: www.todafruta.com.br/noticia_anexo_ arquivo.php?id=39. Acesso em: 7 nov. 2015.

INSTITUTO BRASILEIRO DE GEOGRAFIA E ESTATÍSTICA - IBGE. Produção agrícola municipal. Rio de Janeiro: IBGE, 2017. Disponível em: https:// sidra.ibge.gov.br/pesquisa/pam/tabelas. Acesso em: 18 set. 2018.

JOBIM, C. C.; CECATO, U.; BRANCO, A. F.; BUMBIERIS JÚNIOR, V. H. Subprodutos da 
agroindústria na alimentação de bovinos. In: SIMPÓSIO SOBRE MANEJO ESTRATÉGICO DA PASTAGEM, 3., 2006, Viçosa, MG. Anais...Viçosa, MG: UFV; DZO, 2006. p. 329-358.

LIRA JÚNIOR, W. B.; BEZERRA, S. B. L.; PAULA, T. A.; BEELEN, R. N.; AMORIM, P. L.; BEELEN, P. M. G. Características de silagens de capim-elefante (Pennisetum purpureum) e casca de maracujá in natura. Arquivo Brasileiro de Medicina Veterinária e Zootecnia, Belo Horizonte, v. 70, n. 3, p. 905-912, 2018. DOI: 10.1590/1678-4162-9410

LOUSADA JÚNIOR, J. E.; NEIVA, J. N. M.; RODRIGUEZ, R. M.; PIMENTEL, J. C. M.; LÔBO, R. N. B. Consumo e digestibilidade de subprodutos do processamento de frutas em ovinos. Revista Brasileira de Zootecnia, Viçosa, MG, v. 34, n. 2, p. 659-669, 2005. DOI: $10.1590 / \mathrm{S} 1516-35982005000200036$

MACEDO, C. A. B.; MIZUBUTI, I. Y.; MOREIRA, F. B.; PEREIRA, E. S.; RIBEIRO, E. L. A.; ROCHA, M. A.; RAMOS, B. M. O.; MORI, R. M.; PINTO, A. P.; ALVES, T. C.; CASIMIRO, T. R. Comportamento ingestivo de ovinos recebendo dietas com diferentes níveis de bagaço de laranja em substituição à silagem de sorgo na ração. Revista Brasileira de Zootecnia, Viçosa, MG, v. 36, n. 6, p. 1910-1916, 2007. DOI: 10.1590/ S1516-35982007000800027

MERTENS, D. R. Creating a system for meeting the fiber requirements of dairy cows. Journal of Dairy Science, Champaign, v. 80 , n. 7, p. $1463-1481,1997$. DOI: 10.3168 / jds.S0022-0302 (97) 76075-2

MERTENS, D. R. Predicting intake and digestibility using mathematical models of ruminal function. Journal Animal Science, Savoy, v. 64, n. 6, p. 1548-1558, 1987. DOI: $10.2527 /$ jas $1987.6451548 x$.

NATIONAL RESEARCH COUNCIL - NRC. Nutrient requirements of dairy catlle. $7^{\text {th }}$ ed. Washington: National Academic Press, 2001. 381 p.

PEREIRA, J. C.; CUNHA, D. N. F. V.; CECON, P. R.; FARIA, E. S. Comportamento ingestivo e taxa de passagem de partículas em novilhas leiteiras de diferentes grupos genéticos submetidas a dietas com diferentes níveis de fibra. Revista Brasileira de Zootecnia, Viçosa, MG, v. 36, n. 6, p. 2134-2142, 2007. Suplemento. DOI: 10.1590/S1516-35982007000900025

POLLI, V. A.; RESTLE, J.; SENNA, D. B.; ALMEIDA, S. R. S. Aspectos relativos à ruminação de bovinos e bubalinos em regime de confinamento. Revista Brasileira de Zootecnia, Viçosa, MG, v. 25, n. 5, p. 987-993, 1996.

ROGÉRIO, M. C. P. Valor nutritivo de subprodutos de frutas para ovinos. 2005. Tese (Doutorado em Ciência
Animal) - Universidade Federal de Minas Gerais, Belo Horizonte.

ROGÉRIO, M. C. P.; ARAÚJO, G. G. L.; ALVES, M. J.; NEIVA, J. N. M.; COSTA, H. H. A. Resíduos de frutas na alimentação de gado de leite. In: GONÇALVES, L. C.; BORGES, I.; FERREIRA, P. D. S. Alimentos para gado de leite. Belo Horizonte: FEPMVZ, 2009. cap. 6, p. 88-115.

SENA, J. A. B.; VILLELA, S. D. J.; SANTOS, R. A.; PEREIRA, I. G.; CASTRO, G. H. F.; MOURTHE, M. H. F.; BONFÁ, C. S.; MARTINS, P. G. M. A. Intake, digestibility, performance, and carcass traits of rams provided with dehydrated passion fruit (Passiflora edulis f. flavicarpa) peel, as a substitute of Tifton 85 (Cynodon spp.). Small Ruminant Research, Amsterdam, v. 129, n. 1, p. 18-24, 2015. DOI: 10.1016/j.smallrumres.2015.05.005

SILVA, D. J.; QUEIROZ, A. C. Análise de alimentos: métodos químicos e biológicos. 3. ed. Viçosa, MG: Editora UFV, 2002. 235 p.

SILVA, J. F. C.; LEÃO, M. I. Fundamentos de nutrição de ruminantes. Piracicaba: Livroceres, 1979. 384 p.

SNIFFEN, C. J.; O'CONNOR, J. D.; VAN SOEST, P. J.; FOX, D. G.; RUSSEL, J. B. A net carbohydrate and protein system for evaluating cattle diets: II. Carbohydrate and protein availability. Journal of Animal Science, Champaign, v. 70, n. 11, p. 3562-3577, 1992. DOI: $10.2527 / 1992.70113562 \mathrm{x}$

TOGASHI, C. K.; FONSECA, J. B.; SOARES, R. T. R.; GASPAR, A.; DETMANN, E. Composição em ácidos graxos dos tecidos de frangos de corte alimentados com subprodutos de maracujá. Revista Brasileira de Zootecnia, Viçosa, MG, v. 36, n. 6, p. 2063-2068, 2007. DOI: $10.1590 / \mathrm{S} 1516-35982007000900016$

VALADARES FILHO, S. C.; MAGALHÃES, K. A.; ROCHA JÚNIOR, V. R.; CAPELLE, E. R. Tabelas brasileiras de composição de alimentos para bovinos: CQBAL 2.0. 2. ed. Viçosa, MG: DZO/UFV, 2006. 329 p.

VAN SOEST, P. J. Nutritional ecology of the ruminant. $2^{\text {th }}$ ed. Ithaca: Cornell University Press, 1994. 476 p.

VAN SOEST, P. J.; ROBERTSON, J. B.; LEWIS, B. A. Methods for dietary fiber, neutral detergent fiber, and no starch polysaccharides in relation to animal nutrition. Journal of Dairy Science, Ithaca, v. 74, n. 10, p. 35833597, 1991. DOI: 10.3168/jds.S0022-0302(91)78551-2

WEISS, W. P. Energy prediction equations for ruminant feeds. In: CORNELL NUTRITION CONFERENCE FOR FEED MANUFACTURERS, 61., 1999, Ithaca. Proceedings... Ithaca: Cornell University, 1999. p. 176185. 
